\title{
Local People's Knowledge and Perceptions of Wildlife Conservation in Southeastern Zimbabwe
}

\author{
Edson Gandiwa ${ }^{1}$, Patience Zisadza-Gandiwa ${ }^{2}$, Never Muboko', Elias Libombo ${ }^{3}$, \\ Clayton Mashapa ${ }^{4}$, Rachel Gwazani ${ }^{5}$ \\ ${ }^{1}$ School of Wildlife, Ecology and Conservation, Chinhoyi University of Technology, Chinhoyi, Zimbabwe \\ ${ }^{2}$ Transfrontier Conservation Areas Unit, Zimbabwe Parks and Wildlife Management Authority, Harare, \\ Zimbabwe \\ ${ }^{3}$ Scientific Services, Gonarezhou National Park, Zimbabwe Parks and Wildlife Management Authority, \\ Chiredzi, Zimbabwe \\ ${ }^{4}$ Department of Natural Resources and Wildlife Management, Faculty of Agriculture and Natural Resources, \\ Africa University, Mutare, Zimbabwe \\ ${ }^{5}$ Department of Livestock, Wildlife and Fisheries, Great Zimbabwe University, Masvingo, Zimbabwe \\ Email: ${ }^{*}$ egandiwa@gmail.com
}

Received 11 February 2014; revised 8 March 2014; accepted 5 April 2014

Copyright (C) 2014 by authors and Scientific Research Publishing Inc.

This work is licensed under the Creative Commons Attribution International License (CC BY).

http://creativecommons.org/licenses/by/4.0/

(c) (i) Open Access

\begin{abstract}
This study aimed at examining local people's knowledge and perceptions of wildlife conservation in southeastern Zimbabwe. Data were collected between October and November in 2012 using a purposive sampling approach of households $(n=114)$ in communities adjacent to Gonarezhou National Park. Our results show that local people were aware of the Communal Areas Management Programme for Indigenous Resources (CAMPFIRE) and Gonarezhou, and their associated purposes. However, our results suggest that local people had inadequate knowledge about the Great Limpopo Transfrontier Conservation Area (GLTFCA) and its purpose. Moreover, mixed perceptions about the impact of the GLTFCA on local livelihoods and conservation in the study area were recorded. Finally, the results indicated that improving park-community relationships, education and awareness programmes on natural resources conservation could assist in raising the status of conservation in Gonarezhou and GLTFCA.
\end{abstract}

\section{Keywords}

Community, Gonarezhou National Park, Knowledge, Perception, Protected Area

\footnotetext{
${ }^{*}$ Corresponding author.
} 


\section{Introduction}

Globally, local ecological knowledge and its role in wildlife conservation are increasingly receiving much attention [1]-[3]. Local ecological knowledge is valuable in areas where human communities live inside and around protected areas [4] [5]. This knowledge is derived from the long-standing relationships between local people and their immediate environment resulting in local people having good understanding about natural resources conservation through resource use, education and conservation awareness programmes [6] [7].

A substantial body of research explores local residents' perceptions and attitudes towards protected areas [8]-[11]. However, less research focuses explicitly on different aspects of local residents' knowledge about wildlife conservation, especially in areas with emerging conservation initiatives such as the transboundary natural resources conservation programmes [12]. Information about local people's knowledge and perceptions about conservation is important in wildlife conservation and evaluating the success of conservation projects [13] [14]. Moreover, understanding and acknowledging residents' knowledge and perceptions about wildlife conservation is an important part of a process of engaging with local communities and building constructive relationships between residents and protected area management [15].

Here we contribute to the integrated conservation and development projects literature through examining wildlife conservation related knowledge and perceptions of local people residing in rural communities adjacent to Gonarezhou National Park (hereafter, Gonarezhou), southeastern Zimbabwe, which constitutes part of the Great Limpopo Transfrontier Conservation Area (GLTFCA). Specifically, the study aimed at evaluating the knowledge and perceptions of local people about the Communal Areas Management Programme for Indigenous Resources (CAMPFIRE), Gonarezhou and GLTFCA. Briefly, CAMPFIRE is a government initiative that has been operating in Zimbabwe since 1989 designed to stimulate long-term development, management, and sustainable use of natural resources, especially in buffer zones adjacent to national parks [16] [17]. Gonarezhou is a state protected area whose purpose is to protect and conserve the wilderness, biodiversity and ecological processes of the wild and scenic landscapes within the park boundary and adjacent areas; and the GLTFCA encompasses the management of natural resources in Gonarezhou and the adjacent Kruger National Park (South Africa), Limpopo National Park (Mozambique), and their surrounding areas as one large conservation area for the enhancement of conservation and socio-economic benefits to local communities [18].

\section{Methods and Materials}

\subsection{Study Area}

We assessed the wildlife conservation related knowledge and perceptions of local people living adjacent to Gonarezhou, southeastern Zimbabwe. Gonarezhou was first established as a game reserve around 1934 and later designated a National Park in 1975 [19]. The park covers an area of about $5000 \mathrm{~km}^{2}$ and occurs in a semi-arid savanna ecosystem with annual rainfall ranging between 400 and $600 \mathrm{~mm}$, and is endowed with a wide variety of both large carnivores and herbivore species [12]. CAMPFIRE was established in the early 1990s in the study area whereas the GLTFCA was formally established in 2002 [20] [21]. Local residents in communities adjacent to Gonarezhou practice a combination of subsistence, cash crop farming and livestock production [12].

\subsection{Data Collection and Analysis}

Purposive (or judgement) sampling was used to select a sample of the local respondents and study communities [22]. We used purposive sampling since not all villages within communities (or wards) were involved in CAMPFIRE; hence, we focused on villages that had running CAMPFIRE projects adjacent to Gonarezhou and also part of the GLTFCA. A total of 114 people from five communities were interviewed, all living within a 10 $\mathrm{km}$ distance from the park boundary. Adult respondents ( $\geq 18$ years) from households were selected by walking through the village.

The study used an interview-administered questionnaire. The questionnaire included both open-ended and fixed response questions. The questionnaire was designed to evaluate the knowledge and perceptions of local people about CAMPFIRE, Gonarezhou and GLTFCA. Education and demographic information, including gender and age, were obtained from each respondent. Pre-testing of the questionnaire was undertaken in one village that was not part of the selected sample.

All interviews were conducted by a research assistant who had successfully completed at least four years of 
secondary education recruited from the local community, through oral interviews carried out during the day in the local language (i.e., Shangaan) and/or English from October to November 2012. The total response time was approximately 15 - 25 min. The research assistant administering the survey made initial contact in each village with the local village leaders to seek permission.

Data were grouped and summed by response category. The responses were recorded on a data sheet and later transcribed into English and entered into a Microsoft Excel 2010 database. Where multiple responses were possible on an open-response question, data are presented as the percentage (\%) of respondents giving each response, and may sum to over $100 \%$. Chi-square $\left(\chi^{2}\right)$ tests were applied using the Statistical Package for Social Sciences version 19 for Windows (IBM SPSS Inc, Chicago, USA) to find out if the responses occurred with equal probability.

\section{Results}

\subsection{Demography}

The sample comprised of 64 males (56\%) and 50 females (44\%) $\left(\chi^{2}=1.48, \mathrm{df}=1, P=0.224\right)$. About $46 \%(n=$ 53) of the respondents were between 21 and 40 years, 32\% $(n=36)$ were between 41 and 60 years whereas $22 \%$ $(n=25)$ had more than 60 years $\left(\chi^{2}=10.47, \mathrm{df}=2, P=0.005\right)$. Eleven percent $(n=13)$ of the respondents had no formal education, 39\% $(n=44)$ had primary level education, 28\% $(n=32)$ had secondary education whereas $22 \%(n=25)$ had tertiary education $\left(\chi^{2}=17.72, \mathrm{df}=3, P<0.001\right)$.

\subsection{Knowledge of CAMPFIRE, Gonarezhou and GLTFCA}

A high proportion of respondents largely showed that they had good knowledge about the CAMPFIRE programme within their communities (knew $=108$, did not know $=6 ; n=114 ; \chi^{2}=89.48$, $\mathrm{df}=1, P<0.0001$ ), Gonarezhou (knew $=114$, did not know $=0 ; n=114 ; \chi^{2}=112$, $\left.\mathrm{df}=1, P<0.0001\right)$ and the GLTFCA (knew $=72$, did not know $\left.=42 ; n=114 ; \chi^{2}=7.38, \mathrm{df}=1, P=0.007\right)$. However, respondents showed mixed perceptions on the impact of the GLTFCA on local livelihoods and the study area (positive response $=44$, negative response $=54$ and no effect $=16 ; \chi^{2}=20.42$, $\mathrm{df}=2, P<0.0001$; Figure 1 ).

The majority of the respondents mentioned that CAMPFIRE was working fairly well in the development of their communities and also in the conservation of wildlife (Table 1). Gonarezhou was largely known for wildlife conservation ( $n=81,71 \%$ ), since the park was reported to be near the local communities $(n=33,29 \%)$ and also for providing educational tours ( $n=17,15 \%)$ to local school children.

The GLTFCA was positively perceived to enhance wildlife conservation, create employment and income generating project opportunities (Table 2). In contrast, respondents perceived the GLTFCA as restricting local people's free use of the natural resources within their area and also in the nearby Gonarezhou, leading to an increase in disease transmission from wildlife to livestock and that the implementation of the GLTFCA was slow. A high proportion of the respondents mentioned that they had heard about the GLTFCA from extension work by the Zimbabwe Parks and Wildlife Management Authority (ZPWMA) and CAMPFIRE committee staff and also the mass media (Table 3).

Table 1. Respondent's opinions about CAMPFIRE programmes in communities adjacent to Gonarezhou National Park, Zimbabwe.

\begin{tabular}{|c|c|c|}
\hline Response & Number & $\%$ \\
\hline Working fairly well in the development of the community & 66 & 58 \\
\hline Wildlife conservation & 19 & 17 \\
\hline Safari hunters should pay (fees) directly to community & 13 & 11 \\
\hline CAMPFIRE should benefit the entire community & 12 & 11 \\
\hline Gonarezhou boundary fence negatively affecting the CAMPFIRE projects & 12 & 11 \\
\hline Local people should be trained on managing projects/assets & 8 & 7 \\
\hline
\end{tabular}


Table 2. Perceptions of local people about GLTFCA.

\begin{tabular}{ccc}
\hline Response & Number & $\%$ \\
Positive & & 74 \\
Improved wildlife conservation & 84 & 25 \\
Employment creation & 22 & 19 \\
Local community to generate income from increased tourist inflow & 9 & 8 \\
Improved trade relations between partner countries & 44 & 39 \\
Negative & 30 & 26 \\
Local people no longer free to use natural resources & 24 & 21 \\
Increased disease outbreaks negatively affecting livestock & 9 & 8 \\
High hopes from community but slow implementation of GLTFCA & 8 & 7 \\
Increase in human-wildlife conflicts & & 9 \\
\hline
\end{tabular}

Table 3. Ways in which information about GLTFCA reaches local people.

\begin{tabular}{|c|c|c|}
\hline Response & Number & $\%$ \\
\hline Extension work by ZPWMA and CAMPFIRE staff & 64 & 56 \\
\hline Mass media (i.e., radio and television) & 26 & 23 \\
\hline Community leaders & 15 & 13 \\
\hline Schools & 11 & 10 \\
\hline Non-governmental organisations (NGOs) in the area & 8 & 7 \\
\hline
\end{tabular}

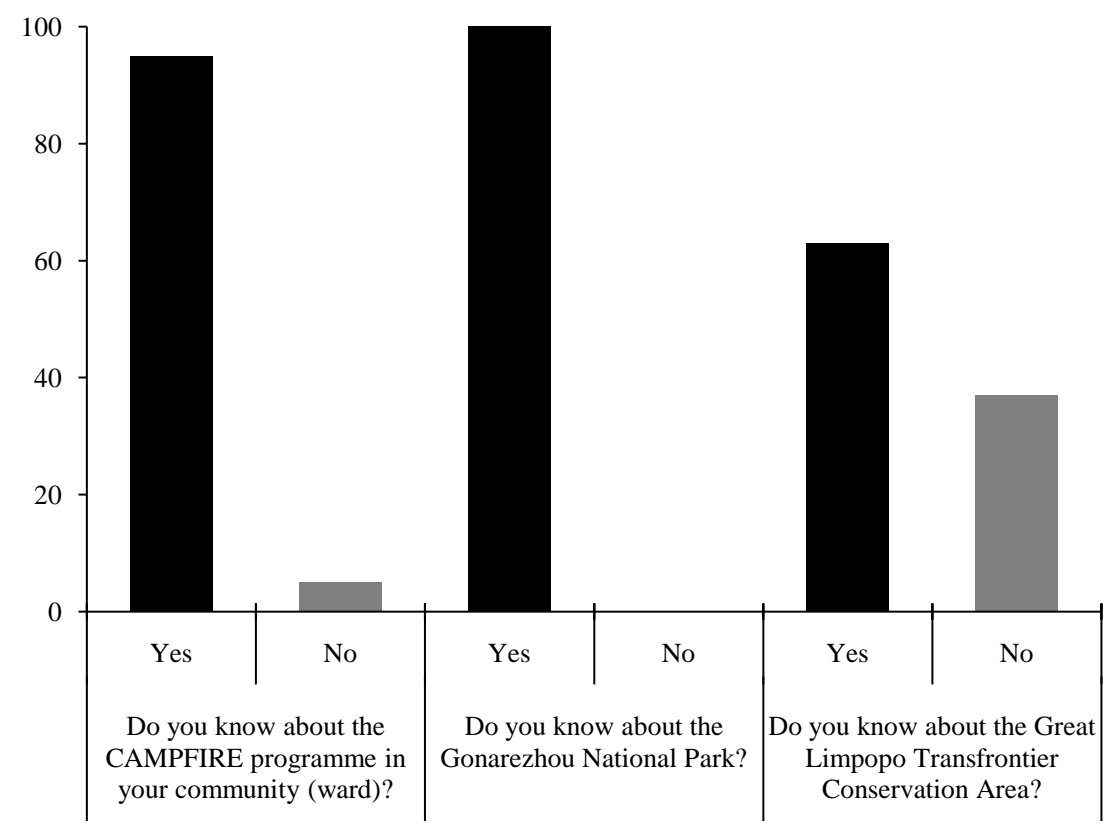

Figure 1. Respondents' knowledge about CAMPFIRE, Gonarezhou and GLTFCA in communities adjacent to Gonarezhou National Park, Zimbabwe. Note: Y-Axis represents \% 


\subsection{Improving the Status of Gonarezhou and GLTFCA}

When asked what could be done to improve the status of Gonarezhou and GLTFCA, improving park-community relationships, enhancing education and awareness programmes, and strengthening law enforcement were among the common suggestions given by the respondents (Table 4).

\section{Discussion}

This study provided an opportunity for the first time to examine local people's knowledge about wildlife conservation in communities living adjacent to Gonarezhou. Our results showed that most respondents had good knowledge about CAMPFIRE, Gonarezhou and their respective purposes compared to the GLTFCA and its purpose. These findings are noteworthy particularly given the increasing global importance of biodiversity conservation. CAMPFIRE and Gonarezhou have been in existence for a longer time as was also shown by the higher proportion of people who indicated that they had good knowledge of the purposes of these two components. Some 10 years after its formulation and designation, $63 \%$ of the respondents indicated that they had some knowledge of the GLTFCA. Moreover, there were mixed opinions about the impact of the GLTFCA on local livelihoods and natural resources conservation in the study area. To some extent there was evidence that the knowledge that the local people had on the GLTFCA is superficial as shown by some negative perceptions. Other previous studies have also found superficial comprehension of environmental knowledge [23].

The fact that not all local people were aware of GLTFCA given its relatively long existence is of concern. Our findings are in line with the suggestion that many people find themselves residing in newly designated transfrontier conservation areas but have little knowledge to what they actually mean, particularly because, the formation of transfrontier conservation areas is a highly political top-down process [24]. Moreover, based on our study findings, we attribute this status to lack of well-coordinated education and awareness programmes in the study area, lack of local people's participation in community-based natural resources conservation programmes and meetings, and shunning school by some local people among other factors. It has been suggested that lack of knowledge on conservation projects have important policy implications. For example, the Convention on Biological Diversity requires signatory countries to promote public awareness of biodiversity and to develop education programmes that emphasize the importance of conserving biodiversity and its sustainable use [25].

Local people's knowledge about natural resources conservation are influenced by education and awareness programmes, services and benefits local people receive from conservation related projects [6] [26]. It could be that the purpose of the GLTFCA is not being communicated effectively, hence, the need for provision of information and interpretation centres in the local communities [4] [27]. Regarding CAMPFIRE, just as observed in other community-based natural resources conservation projects, local people want participatory management and more involvement in decision making rather than have the local management authorities such as rural dis-

Table 4. Suggestions to improve the status of Gonarezhou and GLTFCA.

\begin{tabular}{ccc}
\hline Suggestion & Number & $\%$ \\
\hline Improve park-community relationships & 39 & 34 \\
Enhance education and awareness programmes & 36 & 32 \\
Strengthen law enforcement & 24 & 21 \\
Fence the park and Sengwe corridor & 18 & 16 \\
Employ local people in Gonarezhou & 17 & 12 \\
Improve the marketing of the Gonarezhou & 14 & 11 \\
Implement development projects for local communities & 11 & 10 \\
Need for donor support & 9 & 8 \\
Improve infrastructure in the area & 8 & 7 \\
\hline
\end{tabular}


trict councils (RDCs) solely manage their resources [21] [27].

The indication that there is need to improve park-community relationships, enhance education and awareness programmes, and strengthen law enforcement could be taken as opportunities for strengthening already existing systems or programmes by the wildlife authority (i.e., ZPWMA) and other organisations operating within the GLTFCA. For instance, existing education and awareness programmes are likely to have a positive impact on local people's knowledge about natural resources conservation, if enhanced. Accordingly, education and awareness have been suggested as being important in motivating people to develop or reinforce positive perceptions about biodiversity conservation [23] [28] [29].

Our results show that an assessment into local people's knowledge and perceptions, can produce useful information that could be incorporated into the decision-making process, protected area management planning and also used as a starting point to improve park-community relationships [15]. The most important findings of this study are: i) CAMPFIRE and Gonarezhou and their purposes are largely known by local people; and ii) despite the relatively long period after the formulation and implementation of the GLTFCA, not all local people have informed knowledge about it.

\section{Conclusion}

We conclude by suggesting that it will be valuable for the conservation organisations (both government and non-governmental organisations) to collaboratively develop an environmental education and awareness programme about natural resources conservation to cover the GLTFCA. Moreover, future studies should examine the influence of respondent's education, profession, gender, period of stay and the spatial variation among local people in communities surrounding Gonarezhou on knowledge and perceptions regarding wildlife conservation.

\section{Acknowledgements}

We thank all the respondents who participated in this study, the village leadership for permission to conduct this research and the research assistants who assisted in conducting the interviews. This research was supported by the Gonarezhou Conservation Project. We are also grateful to an anonymous reviewer for the valuable comments and suggestions.

\section{References}

[1] Huntington, H.P. (2011) The Local Perspective. Nature, 478, 182-183. http://dx.doi.org/10.1038/478182a

[2] Berkes, F., Colding, J. and Folke, C. (2000) Rediscovery of Traditional Ecological Knowledge as Adaptive Management. Ecological Applications, 10, 1251-1262. http://dx.doi.org/10.1890/1051-0761(2000)010[1251:ROTEKA]2.0.CO;2

[3] Mmassy, C.E. and Røskaft, E. (2013) Knowledge of birds of conservation interest among the people living close to protected areas in Serengeti, Northern Tanzania. International Journal of Biodiversity Science, Ecosystem Services \& Management, 9, 114-122. http://dx.doi.org/10.1080/21513732.2013.788566

[4] Trakolis, D. (2001) Local People’s Perceptions of Planning and Management Issues in Prespes Lakes National Park, Greece. Journal of Environmental Management, 61, 227-241. http://dx.doi.org/10.1006/jema.2000.0410

[5] Gandiwa, E., Gandiwa, P. and Muboko, N. (2012) Living with Wildlife and Associated Conflicts in Northern Gonarezhou National Park, Southeast Zimbabwe. Journal of Sustainable Development in Africa, 14, 252-260.

[6] Jalilova, G. and Vacik, H. (2012) Local People’s Perceptions of Forest Biodiversity in the Walnut Fruit Forests of Kyrgyzstan. International Journal of Biodiversity Science, Ecosystem Services \& Management, 8, 204-216. http://dx.doi.org/10.1080/21513732.2012.696557

[7] Gandiwa, E., Zisadza-Gandiwa, P., Mashapa, C., Libombo, E. and Muboko, N. (2014) An Assessment of Local People's Participation in Natural Resources Conservation in Southern Zimbabwe. E3 Journal of Environmental Research and Management, 5, 042-046.

[8] Htun, N.Z., Mizoue, N. and Yoshida, S. (2011) Determinants of Local People’s Perceptions and Attitudes toward a Protected Area and Its Management: A Case Study from Popa Mountain Park, Central Myanmar. Society \& Natural Resources, 25, 743-758.

[9] Gillingham, S. and Lee, P.C. (2003) People and Protected Areas: A Study of Local Perceptions of Wildlife CropDamage Conflict in an Area Bordering the Selous Game Reserve, Tanzania. Oryx, 37, 316-325. http://dx.doi.org/10.1017/S0030605303000577 
[10] Dolisca, F., McDaniel, J. and Teeter, L. (2007) Farmers’ Perceptions towards Forests: A Case Study from Haiti. Forest Policy and Economics, 9, 704-712. http://dx.doi.org/10.1016/j.forpol.2006.07.001

[11] Moswete, N.N., Thapa, B. and Child, B. (2012) Attitudes and Opinions of Local and National Public Sector Stakeholders towards Kgalagadi Transfrontier Park, Botswana. International Journal of Sustainable Development \& World Ecology, 19, 67-80. http://dx.doi.org/10.1080/13504509.2011.592551

[12] Gandiwa, E. (2012) Local Knowledge and Perceptions of Animal Population Abundances by Communities Adjacent to the Northern Gonarezhou National Park, Zimbabwe. Tropical Conservation Science, 5, 255-269.

[13] Soto, B., Munthali, S.M. and Breen, C. (2001) Perceptions of the Forestry and Wildlife Policy by the Local Communities Living in the Maputo Elephant Reserve, Mozambique. Biodiversity and Conservation, 10, 1723-1738. http://dx.doi.org/10.1023/A:1012005620906

[14] Sundaresan, S., Bruyere, B., Parker, G., Low, B., Stafford, N. and Davis, S. (2012) Pastoralists’ Perceptions of the Endangered Grevy's Zebra in Kenya. Human Dimensions of Wildlife, 17, 270-281. http://dx.doi.org/10.1080/10871209.2012.662577

[15] Allendorf, T.D., Aung, M. and Songer, M. (2012) Using Residents' Perceptions to Improve Park-People Relationships in Chatthin Wildlife Sanctuary, Myanmar. Journal of Environmental Management, 99, 36-43.

[16] Martin, R.B. (1986) Communal Areas Management Programme for Indigenous Resources (CAMPFIRE). Revised Version, CAMPFIRE Working Document No. 1/86, Branch of Terrestrial Ecology, Department of National Parks and Wild Life Management, Harare.

[17] Logan, B.I. and Moseley, W.G. (2002) The Political Ecology of Poverty Alleviation in Zimbabwe’s Communal Areas Management Programme for Indigenous Resources (CAMPFIRE). Geoforum, 33, 1-14. http://dx.doi.org/10.1016/S0016-7185(01)00027-6

[18] ZPWMA (Zimbabwe Parks and Wildlife Management Authority) (2011) Gonarezhou National Park Management Plan: 2011-2021. Zimbabwe Parks and Wildlife Management Authority, Harare.

[19] Wolmer, W. (2003) Transboundary Conservation: The Politics of Ecological Integrity in the Great Limpopo Transfrontier Park. Journal of Southern African Studies, 29, 261-278. http://dx.doi.org/10.1080/0305707032000060449

[20] Mavhunga, C. and Spierenburg, M. (2009) Transfrontier Talk, Cordon Politics: The Early History of the Great Limpopo Transfrontier Park in Southern Africa, 1925-1940. Journal of Southern African Studies, 35, 715-735. http://dx.doi.org/10.1080/03057070903101920

[21] Gandiwa, E., Heitkönig, I.M.A., Lokhorst, A.M., Prins, H.H.T. and Leeuwis, C. (2013) CAMPFIRE and Human-Wildlife Conflicts in Communities Adjacent to the Northern Gonarezhou National Park, Zimbabwe. Ecology and Society, 18, 7. http://dx.doi.org/10.5751/ES-05817-180407

[22] Tongco, M.D.C. (2007) Purposive Sampling as a Tool for Informant Selection. Ethnobotany Research \& Applications, 5, 147-158.

[23] Ferrie, G.M., Bettinger, T.L., Kuhar, C.W., Lehnhardt, K., Apell, P. and Kasoma, P. (2011) Assessing Community Understanding of Local Environmental Issues in Two Areas of Uganda. Applied Environmental Education \& Communication, 10, 52-62. http://dx.doi.org/10.1080/1533015X.2011.549802

[24] Andersson, J.A., de Garine-Wichatitsky, M., Cumming, D.H., Dzingirai, V. and Giller, K.E. (2013) Transfrontier Conservation Areas: People Living on the Edge. Earthscan/Routledge, London.

[25] Olomí-Solà, M., Zorondo-Rodríguez, F., Triguero-Mas, M., Jha, N. and Reyes-García, V. (2012) Local Residents’ Knowledge about Protected Areas: A Case Study in Dandeli Wildlife Sanctuary, India. Society \& Natural Resources, 25, 410-420. http://dx.doi.org/10.1080/08941920.2011.591034

[26] Newmark, W.D., Leonard, N.L., Sariko, H.I. and Gamassa, D.G.M. (1993) Conservation Attitudes of Local People Living Adjacent to Five Protected Areas in Tanzania. Biological Conservation, 63, 177-183. http://dx.doi.org/10.1016/0006-3207(93)90507-W

[27] Rao, K.S., Nautiyal, S., Maikhuri, R.K. and Saxena, K.G. (2003) Local Peoples’ Knowledge, Aptitude and Perceptions of Planning and Management Issues in Nanda Devi Biosphere Reserve, India. Environmental Management, 31, 168181. http://dx.doi.org/10.1007/s00267-002-2830-4

[28] Vodouhê, F.G., Coulibaly, O., Adégbidi, A. and Sinsin, B. (2010) Community Perception of Biodiversity Conservation within Protected Areas in Benin. Forest Policy and Economics, 12, 505-512. http://dx.doi.org/10.1016/j.forpol.2010.06.008

[29] Barthwal, S.C. and Mathur, V.B. (2012) Teachers' Knowledge of and Attitude toward Wildlife and Conservation: A case Study from Ladakh, India. Mountain Research and Development, 32, 169-175.

http://dx.doi.org/10.1659/MRD-JOURNAL-D-11-00040.1 